\title{
Green tea increases anti-inflammatory tristetraprolin and decreases pro-inflammatory tumor necrosis factor mRNA levels in
} rats

\author{
Heping Cao*1, Meghan A Kelly1, Frank Kari², Harry D Dawson ${ }^{1}$, \\ Joseph F Urban Jr${ }^{1}$, Sara Coves ${ }^{3}$, Anne M Roussel ${ }^{4}$ and Richard A Anderson*1
}

Address: ${ }^{1}$ Nutrient Requirements and Functions Laboratory, Beltsville Human Nutrition Research Center, Agricultural Research Service, US Department of Agriculture, Building 307C, BARC-East, 10300 Baltimore Avenue, Beltsville, MD 20705, USA, ²Office of Clinical Research, National Institute of Environmental Health Sciences, National Institutes of Health, Department of Health and Human Services, Research Triangle Park, NC 27709, USA, ${ }^{3}$ Unilever France, F92842 Rueil Malmaison, France and ${ }^{4}$ Laboratoire de NVMC (Nutrition, Vieillissement et Maladies Cardiovasculaires), Faculte de Pharmacie, Joseph Fourier University, Domaine de la Merci, 38700 La Tronche, France

Email: Heping Cao* - Heping.Cao@ars.usda.gov; Meghan A Kelly - Meg.Kelly@ars.usda.gov; Frank Kari - kari1@niehs.nih.gov; Harry D Dawson - Harry.Dawson@ars.usda.gov; Joseph F Urban - Joe.Urban@ars.usda.gov; Sara Coves - Sara.Coves@unilever.com; Anne M Roussel - Anne-Marie.Roussel@ujf-grenoble.fr; Richard A Anderson* - Richard.Anderson@ars.usda.gov

* Corresponding authors

Published: 05 January 2007

Journal of Inflammation 2007, 4:I doi:I0.1 186/1476-9255-4-I
Received: 20 October 2006

Accepted: 05 January 2007

This article is available from: http://www.journal-inflammation.com/content/4/I/I

(c) 2007 Cao et al; licensee BioMed Central Ltd.

This is an Open Access article distributed under the terms of the Creative Commons Attribution License (http://creativecommons.org/licenses/by/2.0), which permits unrestricted use, distribution, and reproduction in any medium, provided the original work is properly cited.

\begin{abstract}
Background: Tristetraprolin (TTP/ZFP36) family proteins have anti-inflammatory activity by binding to and destabilizing pro-inflammatory mRNAs such as Tnf mRNA, and represent a potential therapeutic target for inflammation-related diseases. Tea has anti-inflammatory properties but the molecular mechanisms have not been completely elucidated. We hypothesized that TTP and/or its homologues might contribute to the beneficial effects of tea as an anti-inflammatory product.
\end{abstract}

Methods: Quantitative real-time PCR was used to investigate the effects of green tea $(0, \mathrm{I}$, and 2 $\mathrm{g}$ solid extract $/ \mathrm{kg}$ diet) on the expression of Ttp family genes (Ttp/Tis / I/Zfp36, Zfp36II/Tis / l b, Zfp36/2/Tis I Id, Zfp36/3), pro-inflammatory genes (Tnf, Csf2/Gm-csf, Ptgs2/Cox2), and Elavll//Hua/Hur and $V$ egf genes in liver and muscle of rats fed a high-fructose diet known to induce insulin resistance, oxidative stress, inflammation, and TNF-alpha levels.

Results: Ttp and Zfp36II mRNAs were the major forms in both liver and skeletal muscle. Ttp, Zfp36II, and Zfp3612 mRNA levels were more abundant in the liver than those in the muscle. Csf2/ $\mathrm{Gm}$-csf and Zfp3613 mRNAs were undetectable in both tissues. Tea (I g solid extract $/ \mathrm{kg}$ diet) increased Ttp mRNA levels by $50-140 \%$ but Tnf mRNA levels decreased by $30 \%$ in both tissues, and Ptgs $2 /$ Cox 2 mRNA levels decreased by $40 \%$ in the muscle. Tea ( $2 \mathrm{~g}$ solid extract $/ \mathrm{kg}$ diet $)$ increased ElavlI/Hua/Hur mRNA levels by $40 \%$ in the liver but did not affect any of the other mRNA levels in liver or muscle.

Conclusion: These results show that tea can modulate Ttp mRNA levels in animals and suggest that a post-transcriptional mechanism through TTP could partially account for tea's antiinflammatory properties. The results also suggest that drinking adequate amounts of green tea may play a role in the prevention of inflammation-related diseases. 


\section{Background}

Recent investigations have established a mechanism for the regulation of inflammatory responses at the post-transcriptional level by tristetraprolin (TTP) family of CCCH tandem zinc finger proteins (ZFP). TTP family consists of three known members in mammals (ZFP36 or TTP, ZFP36L1 or TIS11B, and ZFP36L2 or TIS11D) and the fourth member in mouse and rat but not in humans (ZFP36L3) [1,2]. TTP (TIS11, GOS24, or NUP475), the best-studied family member, is the product of the immediate-early response gene Zfp36 in the mouse (ZFP36 in humans, refer to "Abbreviations" for the nomenclature of genes, mRNAs, and proteins) [3-5]. TTP binds to AU-rich elements (AREs) in some mRNAs and destabilizes those transcripts encoding proteins such as tumor necrosis factor- $\alpha$ (TNF- $\alpha$ ) [6-9], granulocyte-macrophage colonystimulating factor (GM-CSF) $[10,11]$, and cyclooxygenase 2 (COX-2) [12]. The mRNAs encoding TNF- $\alpha$ and GMCSF are stabilized in TTP knockout mice and in cells derived from them $[8,10]$. Excessive secretion of these cytokines in TTP knockout mice results in a severe systemic inflammatory response including arthritis, autoimmunity, and myeloid hyperplasia $[13,14]$. In contrast, upregulation of TTP reduces inflammatory responses in macrophages [15]. These lines of evidence support the conclusion that TTP is an anti-inflammatory protein or arthritis suppressor.

Agents that induce Ttp gene expression may have potential therapeutic value for the prevention and/or treatment of inflammation-related diseases. A number of agents have been shown to increase Ttp mRNA and/or protein levels in mammalian cells. The inducible agents include growth factors (insulin, insulin-like growth factor I, epidermal growth factor, fibroblast growth factor, platelet-derived growth factor, and fetal calf serum) [3,4], cytokines (TNF$\alpha$, GM-CSF, and interferon-gamma) $[4,5,8,15]$ and zinc [16]. However, Ttp gene expression is also induced by tumor promoters (phorbol 12-myristate 13-acetate and tetradecanoyl phorbol acetate) $[3,5]$ and bacterial endotoxin lipopolysaccharide (LPS) $[8,17,18]$. Finally, Ttp gene expression is induced by viral infection [19]. The fact that most of these agents also increase the expression levels of pro-inflammatory cytokines such as TNF- $\alpha$ in the same cells and/or tissues $[8,20]$ may limit the therapeutic potential of these agents. Therefore, it is important to search for other agents with the potential to up-regulate anti-inflammatory but down-regulate pro-inflammatory gene expression.

Tea (Camellia sinensis) is a popular beverage worldwide. Recent studies indicate that tea has a wide range of effects on animal and human health. A number of studies have indicated that green tea has anti-inflammatory properties [21]. Tea has been reported to have beneficial effects in conditions such as collagen-induced arthritis [22], inflammatory bowel disease [23] and carrageenan-induced paw edema [24]. However, the molecular mechanism of tea's anti-inflammatory property has not been completely elucidated. We hypothesized that TTP and/or its homologues might be involved in the beneficial effects of tea as an antiinflammatory product.

A high fructose diet has been used as a model for the study of insulin resistance and oxidative stress in rats [25]. Overproduction of free radicals under oxidative stress is associated with inflammation. TNF- $\alpha$ levels are increased in rat muscle by high fructose diet, which is one of the determinants of insulin resistance in skeletal muscle [26,27]. A high fructose diet was also shown to activate inflammatory pathways in the liver [28]. Since liver and muscle are two of the most insulin-responsive organs and Ttp gene expression is induced by insulin [3], we hypothesized that TTP and/or its homologues might be involved in the inflammatory response induced by a high-fructose diet in rat liver and muscle, and that green tea might possess beneficial effects in high fructose-fed rats. Therefore, the demonstration of the effects of tea on inflammation-related gene expression in this model is important and complementary of its known antioxidant effects.

In this study, quantitative real-time PCR was used to investigate the expression profiles and the effects of green tea on the expression levels of the anti-inflammatory Ttp family mRNAs and some of the pro-inflammatory mRNAs known to be regulated by TTP family proteins. Our results showed that liver had more abundant Ttp family mRNA levels than skeletal muscle, and that Ttp mRNA levels were increased significantly and Tnf mRNA levels were reduced in the liver and skeletal muscle of rats fed a high-fructose diet and given $1 \mathrm{~g}$ of green tea extract $/ \mathrm{kg}$ in the diet.

\section{Methods}

\section{Animals, fructose-rich diet, and green tea extract}

Male Wistar rats ( 6 weeks old, $150 \pm 10 \mathrm{~g}$ ) from Charles River Laboratories (Les Oncins, France) were housed individually in thermoformed polystyrene cages in accordance with standards accredited by the French Ministries of Agriculture and Environment. The rats were kept under the conditions with a 12-h light:12-h dark schedule, a room temperature of $21 \pm 1^{\circ} \mathrm{C}$, and a relative humidity of $55 \%$. The fructose-rich diet used in this study contained $60 \%(\mathrm{w} / \mathrm{w})$ fructose, $20.7 \%$ casein, $5 \%$ corn oil, $8 \%$ alphacel, $1 \%$ mineral mix, $1 \%$ vitamin mix, and $0.3 \%$ casein (SAFE, 89290, Augis, France). The green tea solid extract used in this study contained $12.75 \%(\mathrm{w} / \mathrm{w})$ epigallocatechin-3-gallate (EGCG), 9.21\% epigallocatechin (EGC), 3.73\% epicatechin gallate (ECG), 2.4\% epicatechin (EC), 5.94\% caffeine, and $0.195 \%$ L-theanine (Unilevel France). 


\section{Experimental design}

All rats were fed a standard Purina chow for one week before being randomly divided into three groups with 10 rats per group. The first group of rats was given a highfructose diet that has been shown to induce insulin resistance and oxidative stress (diet control). The second group of rats was given the high-fructose diet plus $1 \mathrm{~g}$ of green tea solid extract/kg diet ( $1 \mathrm{~g}$ tea) and the third group of rats was given the high-fructose diet plus $2 \mathrm{~g}$ of green tea solid extract/kg diet ( $2 \mathrm{~g}$ tea). Animals were sacrificed after 6 weeks on the diet. Food intake for rats fed the diet control, $1 \mathrm{~g}$ tea, and $2 \mathrm{~g}$ tea was $20.7 \pm 0.8,20.5 \pm 0.9$, and $20.3 \pm 1.5 \mathrm{~g} / \mathrm{d}$, respectively. The body weight for rats fed the diet control, $1 \mathrm{~g}$ tea, and $2 \mathrm{~g}$ tea for 6 weeks was $360 \pm$ $7,350 \pm 5$, and $353 \pm 7 \mathrm{~g}$, respectively. The trend of decreased body weight in treated rats was not significant after 6 weeks of diet. The mean body gain by week for rats fed the diet control, $1 \mathrm{~g}$ tea, and $2 \mathrm{~g}$ tea was about 35, 34, and $34.5 \mathrm{~g}$, respectively. These data are in agreement with a previous report in which the same diet was used and a similar evolution in body weight was reported [29]. The liver and skeletal muscle were removed from the rats, frozen in liquid nitrogen, and stored at $-80^{\circ} \mathrm{C}$. All procedures were in accord with guidelines of the National Institutes of Health and were approved by the French Army Ethical Committee.

\section{RNA isolation}

Rat liver and muscle were ground into powder under liquid nitrogen. About 200-400 mg of the tissue powder was homogenized in $4 \mathrm{ml}$ of $\mathrm{TRI}_{\mathrm{ZOL}}$ reagent (Invitrogen, Carlsbad, CA, USA) in a 15-ml Falcon tube. RNA was isolated according to the manufacturer's instructions. The RNA pellet was suspended in $20 \mu \mathrm{l}$ DEPC-treated water. RNA integrity and concentrations were determined using RNA 6000 Nano Assay Kit and the Bioanalyzer 2100 according to the manufacturer's instructions (Agilent Technologies, Palo Alto, CA, USA) with RNA 6000 Ladder as the standards (Ambion, Inc., Austin, TX, USA).

\section{cDNA synthesis}

Total cDNA synthesis was performed in 0.2-ml microfuge tubes using the ImProm-II Reverse Transcription System (Promega, Madison, WI). The reaction mixture $(20 \mu \mathrm{l})$ contained $5 \mu \mathrm{g}$ total RNA, $1 \mu \mathrm{g}$ oligo(dT) ${ }_{15}$ primer (Invitrogen), $0.25 \mu \mathrm{g}$ random primers (Invitrogen), $500 \mu \mathrm{M}$ dNTPs, $5 \mathrm{mM} \mathrm{MgCl}_{2}, 2.5 \mu \mathrm{RNasin}$ ribonuclease inhibitor, and $5 \mu \mathrm{l}$ ImProm-II reverse transcriptase in $1 \times$ ImProm-II reaction buffer. The cDNA synthesis reactions were carried out at $42^{\circ} \mathrm{C}$ for $60 \mathrm{~min}$.

\section{PCR primers and TaqMan probes}

The primers and probes were designed using Primer Express software (Applied Biosystems, Foster City, CA, USA) and were synthesized by Biosearch Technologies,
Inc. (Navato, CA, USA). The mRNA names, GenBank accession numbers, amplicon sizes, and the sequences (5' to $3^{\prime}$ ) of the forward primers, TaqMan probes (TET BHQ1), and reverse primers, respectively, are described in Table 1.

\section{Quantitative real-time PCR assays}

The TaqMan reaction mixture $(25 \mu \mathrm{l})$ contained $25 \mathrm{ng}$ of total RNA-derived cDNAs, $200 \mathrm{nM}$ each of the forward primer, reverse primer, and TaqMan probe, and $12.5 \mu \mathrm{l}$ of 2× Absolute QPCR Mix (ABgene House, Epson, Surrey, $U K)$. The reactions were performed in 96-well plates in a ABI Prism 7700 real-time PCR instrument (Applied Biosystems) [30]. The thermal cycle conditions were as follows: $2 \mathrm{~min}$ at $50^{\circ} \mathrm{C}$ and $10-15 \mathrm{~min}$ at $95^{\circ} \mathrm{C}$, followed by $40-60$ cycles at $95^{\circ} \mathrm{C}$ for $15 \mathrm{~s}$ and $60^{\circ} \mathrm{C}$ for $60 \mathrm{~s}$. Fluorescence signals measured during amplification were considered positive if the fluorescence intensity was more than 20 -fold greater than the standard deviation of the baseline fluorescence [30]. The $\Delta \Delta C_{T}$ method of relative quantification was used to determine the fold change in expression [31]. This was done by first normalizing the resulting threshold cycle $\left(C_{T}\right)$ values of the target mRNAs to the $C_{T}$ values of the internal control Rpl32 in the same samples $\left(\Delta C_{T}=C_{T \text { Target }}-C_{T \text { Rpl32 }}\right)$. It was further normalized with the diet control (samples with only the high-fructose diet but without tea supplement) $\left(\Delta \Delta C_{T}=\Delta C_{T \text { Tea }}-\Delta C_{T \text { Diet }}\right)$. The fold change in expression was then obtained $\left(2^{-\Delta \Delta C_{T}}\right)$.

\section{Statistical analyses}

The data were analyzed by SigmaStat 3.1 software (Systat Software, Inc., Point Richmond, CA) using One Way Analysis of Variance (ANOVA). Multiple comparisons were performed with Duncan's Multiple Range Test. Values with different lower case and upper case letters displayed above the columns of the figures are significantly different at $p<0.05$ and $p<0.01$, respectively.

\section{Results \\ Ttp family and other selected mRNA levels in rat liver and muscle}

There are four forms of the anti-inflammatory TTP family proteins in rats and mice (TTP/ZFP36, TIS11B/ZFP36L1, TIS11D/ZFP36L2, and ZFP36L3) [1,2]. We examined the expression levels of these four forms of genes in the liver and skeletal muscle of rats fed a high-fructose diet known to induce insulin resistance and oxidative stress [25]. The $C_{T}$ values of the Ttp family and the internal control Rpl32 mRNAs and the relative ratio of Ttp family mRNAs in the liver and muscle are shown in Table 2. The $C_{T}$ values of Rpl32 in the liver and muscle were essentially the same 
Table I: Nucleotide sequences of real-time PCR primers and TaqMan probes

Man probes

mRNA

Accession No

Amplicon size

GGTACCCCAGGCTGGCTTT

AACTCAATATAATCCTGCCTTAGCCTT

ACCACCACCCTCGTGTCCGCC

TGCGAACGCCCACGAT

GAGGGCACCTCCCAACCT

TTGCAATTTCGACCATTACAGGACCCA

CGAACTGCGTACCCTGTCAAG

CACCCCAAGTACAAGACGGAGCCTTG

TGCTCCCCACGGGAGCCG

AGCTGTGCTGCTCTGCGCT

TCACCCGGCCTTGGAAGCATGTAGA

AAGTTTGCAGCCAATCCCAACCAGAA

CCCGGTTTAAATCCTGGAGCG

TGTCCCTGGAAGAACACAGCCAATGTG

GATCCAGTACCCGAGCAGTCA

AACCGAAAAGCCATTGTAGAAA
Reverse primer (5' to 3')

ACCTGTAACCCCAGAACTTGGA

CTTCGCTCAAGTCAAAAATGG

TGACAGAAGTGTGGTCGACATTT

GCCAACGCTGTGGAAGGT

TGACCCGTAGGGCAATTACA

CATTCCCCACGGTTTTGACATG

GGAGGCTCAGAGCTTCTTTGA

GCGAGAGGAGAGCCATGTTT

CGCTCTGAACAAGGCTCACA

TCTCCTTTTTTTTTGGTCTGCAT

CCTGGCGTTGGGATTGG 
and the results validated the assumption of using the Rpl32 mRNA level as an internal control for the normalization of gene expression levels. Ttp and Tis $11 \mathrm{~b}$ mRNAs were the two dominant forms of Ttp family messages in both liver and muscle. In liver, the relative levels of Ttp, Tis $11 \mathrm{~b}$, and Tis $11 \mathrm{~d}$ mRNAs were $100 \%, 148 \%$, and $6 \%$, respectively. In muscle, the relative levels of Ttp, Tis $11 \mathrm{~b}$, and Tis $11 \mathrm{~d}$ mRNAs were $100 \%, 70 \%$, and $15 \%$, respectively. Zfp36l3 mRNA was undetectable by 50 cycles of PCR in the liver or muscle. As a positive control for the PCR assay, Zfp36l3 mRNA was detected in two cell lines (data not shown). Ttp, Tis11b, and Tis11d mRNA levels were more abundant in the liver than those in the muscle, and were 5, 12.5, and 2 fold of those in the muscle, respectively (Table 2).

Low levels of Tnf and Ptgs2/Cox2 mRNAs were detected in both liver and muscle (Table 2). Between these two tissues, Tnf mRNA levels in the liver were about 2-fold of those in the muscle. Conversely, Ptgs 2 mRNA levels in the liver were about $40 \%$ of those in the muscle. The expression levels of $\mathrm{Hu}$ antigen R (Elavl1/Hua/Hur), vascular endothelial growth factor a (Vegfa) and Vegfb in the liver were about 2.5 -fold, 2 -fold, and $25 \%$ of those in the muscle, respectively. Csf2/Gm-csf mRNA was undetectable by 50 cycles of PCR in the liver or muscle. As a positive con- trol for the assay, Csf2 mRNA was detected in mouse RAW264.7 cells (data not shown).

\section{Green tea increases Ttp mRNA levels in rat liver}

Green tea (1 g solid extract/kg diet) increased Ttp mRNA levels by $50 \%(P=0.003)$ but did not have statistically significant effects on Tis $11 \mathrm{~b}$ or Tis11d mRNA levels in the liver (Fig. 1). Green tea (2 g solid extract $/ \mathrm{kg}$ diet) did not have statistically significant effects on Ttp, Tis $11 \mathrm{~b}$, or Tis11d mRNA levels in the liver. Zfp36l3 mRNA was not detected by the PCR assays in the liver of rats treated with or without the tea supplement.

\section{Green tea increases Ttp mRNA levels in rat muscle}

Green tea (1 g solid extract/kg diet) increased Ttp mRNA levels by $140 \%(\mathrm{P}<0.001)$ but did not have statistically significant effects on Tis $11 \mathrm{~b}$ or Tis $11 \mathrm{~d}$ mRNA levels in the skeletal muscle (Fig. 2). Green tea (2 g solid extract $/ \mathrm{kg}$ diet) did not have statistically significant effects on Ttp, Tis11b, or Tis11d mRNA levels in the muscle. Zfp36l3 mRNA was not detected by the PCR assays in the muscle of rats treated with or without the tea supplement. The percentage increases of Ttp mRNA in the muscle (Fig. 2) were higher than those in the liver (Fig. 1) but the net increases of Ttp mRNA levels in the liver were more than those in the muscle since Ttp mRNA levels in the liver

Table 2: Ttp family and other selected mRNA levels in rat liver and muscle

\begin{tabular}{|c|c|c|c|c|}
\hline Tissue & mRNA & Cycle of threshold $\left(C_{T} \pm S D\right)$ & $\begin{array}{c}\text { Expression ratio } \\
\text { (relative to Ttp) (Fold) }\end{array}$ & $\begin{array}{c}\text { Expression ratio } \\
\text { (relative to liver) (Fold) }\end{array}$ \\
\hline \multirow[t]{11}{*}{ Liver } & Rpl32 & $18.35 \pm 0.40$ & Internal control & 1.00 \\
\hline & Ttp/Tis I I/Zfp36 & $21.23 \pm 0.43$ & 1.00 & 1.00 \\
\hline & Zfp36II/TisI Ib & $20.67 \pm 0.54$ & 1.48 & 1.00 \\
\hline & Zfp3612/TisIId & $25.19 \pm 0.36$ & 0.06 & 1.00 \\
\hline & Zfp3613 & 0.00 & 0.00 & \\
\hline & Tnf & $39.12 \pm 0.77$ & & 1.00 \\
\hline & Csf2/Gm-csf & 0.00 & & \\
\hline & Ptgs2/Cox2 & $33.09 \pm 0.39$ & & 1.00 \\
\hline & Vegfa & $20.36 \pm 0.27$ & & 1.00 \\
\hline & Vegfb & $25.69 \pm 0.56$ & & 1.00 \\
\hline & ElavlI/Hua/Hur & $22.46 \pm 0.22$ & & 1.00 \\
\hline \multirow[t]{11}{*}{ Muscle } & Rpl32 & $18.26 \pm 0.26$ & Internal control & 1.03 \\
\hline & Ttp/Tis I I/Zfp36 & $23.81 \pm 0.97$ & 1.00 & 0.21 \\
\hline & Zfp36II/Tis I Ib & $24.32 \pm 0.85$ & 0.70 & 0.07 \\
\hline & Zfp3612/Tis I Id & $26.51 \pm 0.85$ & 0.15 & 0.49 \\
\hline & Zfp3613 & 0.00 & 0.00 & \\
\hline & Tnf & $40.05 \pm 0.55$ & & 0.59 \\
\hline & Csf2/Gm-csf & 0.00 & & \\
\hline & Ptgs2/Cox2 & $31.55 \pm 0.83$ & & 2.42 \\
\hline & Vegfa & $21.14 \pm 0.35$ & & 0.59 \\
\hline & Vegfb & $23.66 \pm 0.29$ & & 4.27 \\
\hline & ElavlI/Hua/Hur & $23.54 \pm 0.18$ & & 0.42 \\
\hline
\end{tabular}

Twenty-five ng of RNA-derived cDNAs were used for the quantitation of mRNA levels using 40-60 cycles of real-time PCR program. The mean $C_{T}$ (cycle of threshold) values and standard deviations $(n=5-8)$ are shown in the table. The relative ratios of mRNA levels were calculated using the double delta $C_{T}$ method normalized with Rpl32 $C_{T}$ value as the internal control and $T$ tp $C_{T}$ value or liver $C_{T}$ value as the calibrator. 
Diet control $\square 1 \mathrm{~g}$ tea $\square 2 \mathrm{~g}$ tea

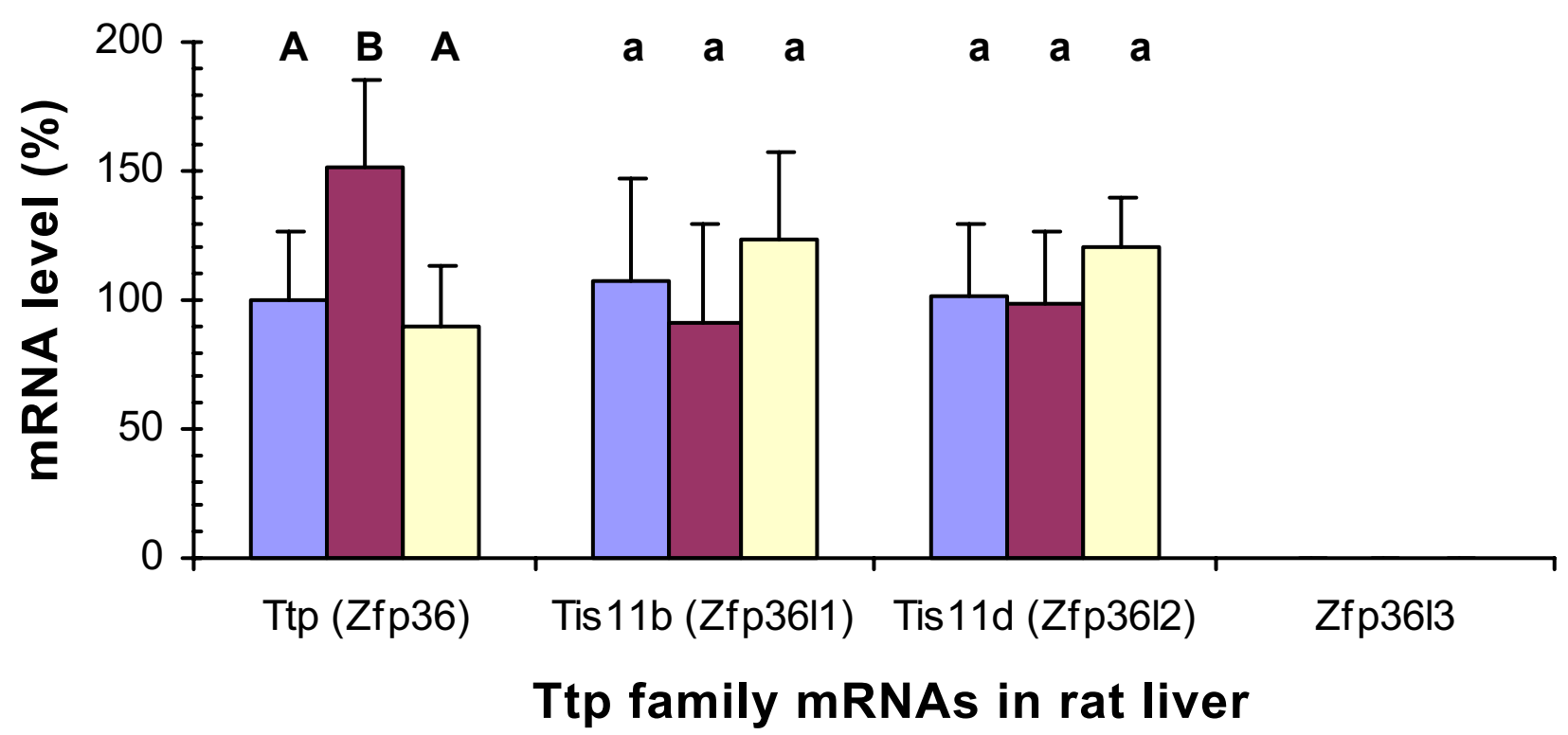

\section{Figure I}

Green tea effects on Ttp family mRNA levels in rat liver. Total RNAs were isolated from livers of rats with metabolic syndrome induced by a high-fructose diet and reversely transcribed into cDNAs. Twenty-five nanograms of RNA-derived cDNAs were used for quantitative real-time PCR assays. The $\Delta \Delta C_{T}$ method of relative quantification was used to determine the fold change in expression. The results represent the percentage means and the standard deviations from 5-8 samples with 2-4 repetitions of each sample. Values with different upper case and lower case letters displayed above the columns of the figure are significantly different at $p<0.01$ and $p<0.05$, respectively.

were about 5-fold higher than those in the muscle (Table 2).

\section{Green tea decreases Tnf mRNA levels in rat liver}

The increased levels of the anti-inflammatory Ttp mRNA level with $1 \mathrm{~g}$ of green tea solid extract per $\mathrm{kg}$ of diet shown above suggest that green tea might have destabilizing effects on pro-inflammatory ARE-containing mRNAs such as Tnf mRNA. Therefore, we analyzed the expression levels of Tnf, Csf2/Gm-csf, and Ptgs2/Cox2 mRNAs, whose stability are known to be decreased by TTP $[8,10,12]$, in the liver of rats fed with the high-fructose diet with or without 1 or $2 \mathrm{~g}$ of green tea solid extract per $\mathrm{kg}$ of diet (Fig. 3). PCR assays showed that green tea extract at $1 \mathrm{~g}$ decreased Tnf mRNA levels by $30 \%(\mathrm{P}=$ 0.017 ) but did not have statistically significant effects on Ptgs 2 mRNA levels in the liver. However, green tea extract at $2 \mathrm{~g}$ did not have statistically significant effects on Tnf or Ptgs2 mRNA levels in the liver. Csf2 mRNA was not detected by the PCR assays in the liver of rats treated with or without the tea supplement.

\section{Green tea decreases Tnf and Ptgs2/Cox2 mRNA levels in rat muscle}

PCR analyses showed that green tea extract at $1 \mathrm{~g}$ decreased Tnf and Ptgs 2 mRNA levels in the skeletal mus- cle by $30 \%(\mathrm{P}=0.008)$ and $40 \%(\mathrm{P}=0.042)$, respectively (Fig. 4). However, green tea extract at $2 \mathrm{~g}$ did not have statistically significant effects on Tnf or Ptgs 2 mRNA levels in the muscle. Csf2 mRNA was not detected by the PCR assays in the muscle of rats treated with or without the tea supplement.

\section{Green tea does not affect Vegf mRNA levels in rat liver or muscle}

Similar to Tnf and Ptgs 2 mRNAs, Vegfa and Vegfb mRNAs are also ARE-containing mRNAs which are destabilized by TIS11B protein [32]. We investigated if green tea affected their mRNA levels in the liver and skeletal muscle of rats fed the high-fructose diet. PCR assays showed that green tea extract at 1 or $2 \mathrm{~g}$ did not have statistically significant effects on Vegfa or Vegfb mRNA levels in the liver or muscle (data not shown).

\section{Green tea increases ElavlI/HualHur mRNA levels in rat liver}

In contrast to TTP, ELAVL1 is known to be a stabilizing protein for some ARE-containing mRNAs [33-35]. We investigated if green tea affected Elavl1 mRNA levels in the liver and muscle of rats fed with the same high-fructose diet. Green tea extract at $1 \mathrm{~g}$ did not statistically significantly affect Elavl1 mRNA levels in the liver or muscle. 


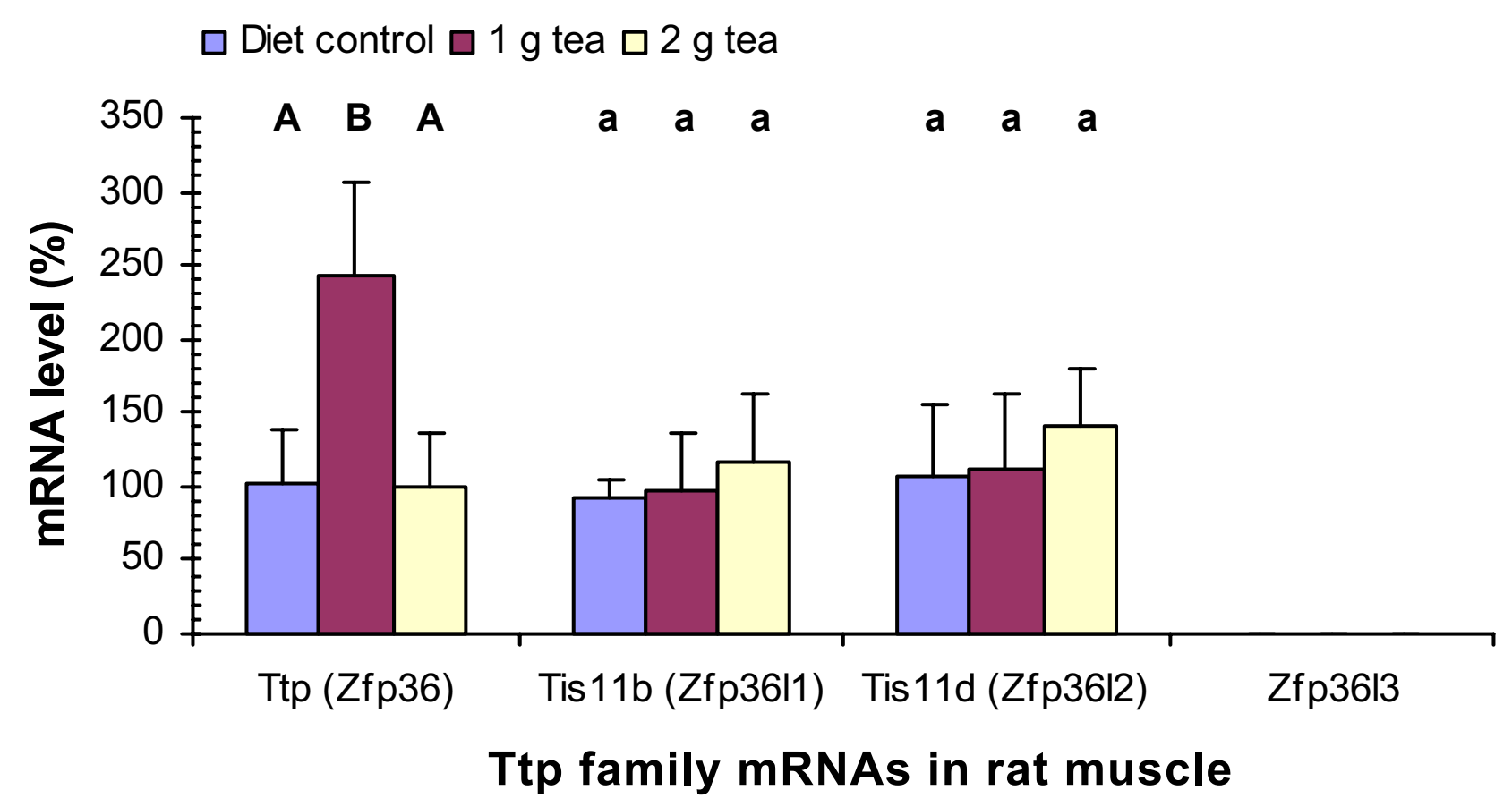

Figure 2

Green tea effects on Ttp family mRNA levels in rat muscle. RNA isolation, cDNA synthesis, real-time PCR assays, and statistical analyses were described in Fig. I legend.

However, green tea extract at $2 \mathrm{~g}$ significantly increased the mRNA levels by $40 \%(P=0.007)$ in the liver but not in the muscle (Fig. 5).

\section{Discussion}

TTP is an anti-inflammatory protein with the potential as a therapeutic target for the prevention and/or treatment of inflammation-related diseases. Previous studies have shown that Ttp mRNA and/or TTP protein levels are increased in mammalian cells by a wide range of agents. However, the fact that most of the same agents also increase the expression levels of pro-inflammatory cytokines in the same cells and/or tissues $[8,20]$ limits these agents' therapeutic potential. In this study, we determined that green tea possessed the ability to increase Ttp but decrease Tnf gene expression in rats fed a high fructose diet known to induce insulin resistance, oxidative stress, and inflammation.

Tea is the most consumed beverage in the world and there are numerous reports of the health benefits of tea. One of the effects of tea is its anti-inflammatory property. In this study, we explored the relationship between green tea and the mRNA levels of some pro-inflammatory and antiinflammatory genes in the liver and muscle of rats with metabolic syndrome induced by a high-fructose diet. We demonstrated that a low dose of green tea $(1 \mathrm{~g}$ solid extract/kg diet) significantly increased the mRNA levels of the anti-inflammatory protein TTP and decreased those of the pro-inflammatory TNF- $\alpha$ in both liver and muscle of rats and also decreased Ptgs 2 mRNA in the muscle. The induction of Ttp and reduction of Tnf mRNAs by green tea in rats suggests that at least part of the mechanisms of tea's anti-inflammatory effects may be involved in TTP at the post-transcriptional level.

Previous investigations have suggested that the mechanism of tea's anti-inflammatory effects also involves the regulation of gene transcription. Tea affects a number of important molecular targets including TNF- $\alpha$ [36], interleukin 2 (IL-2) [23], signal transducer and activator of transcription-1 $\alpha$ (STAT-1 $\alpha)$ [37], inducible nitric-oxide synthase (iNOS) [38], nuclear factor-kappa B (NF-кB), insulin activity [39-41], and affects DNA and RNA directly [42]. TNF- $\alpha$ plays a crucial role in inflammation. NF- $\kappa \mathrm{B}$, an oxidative stress-sensitive nuclear transcription factor, controls the expression of Tnf and other genes. It was shown that green tea polyphenol EGCG inhibited LPSmediated Tnf mRNA levels by blocking NF- $\kappa$ B activation in macrophage RAW264.7 cells [36]. Therefore, it was proposed that the anti-inflammatory mechanism of green tea polyphenols is mediated at least in part through down-regulation of Tnf gene expression by blocking NF$\kappa \mathrm{B}$ activation [36]. Taken together, the molecular mecha- 
Diet control $\square 1 \mathrm{~g}$ tea $\square 2 \mathrm{~g}$ tea

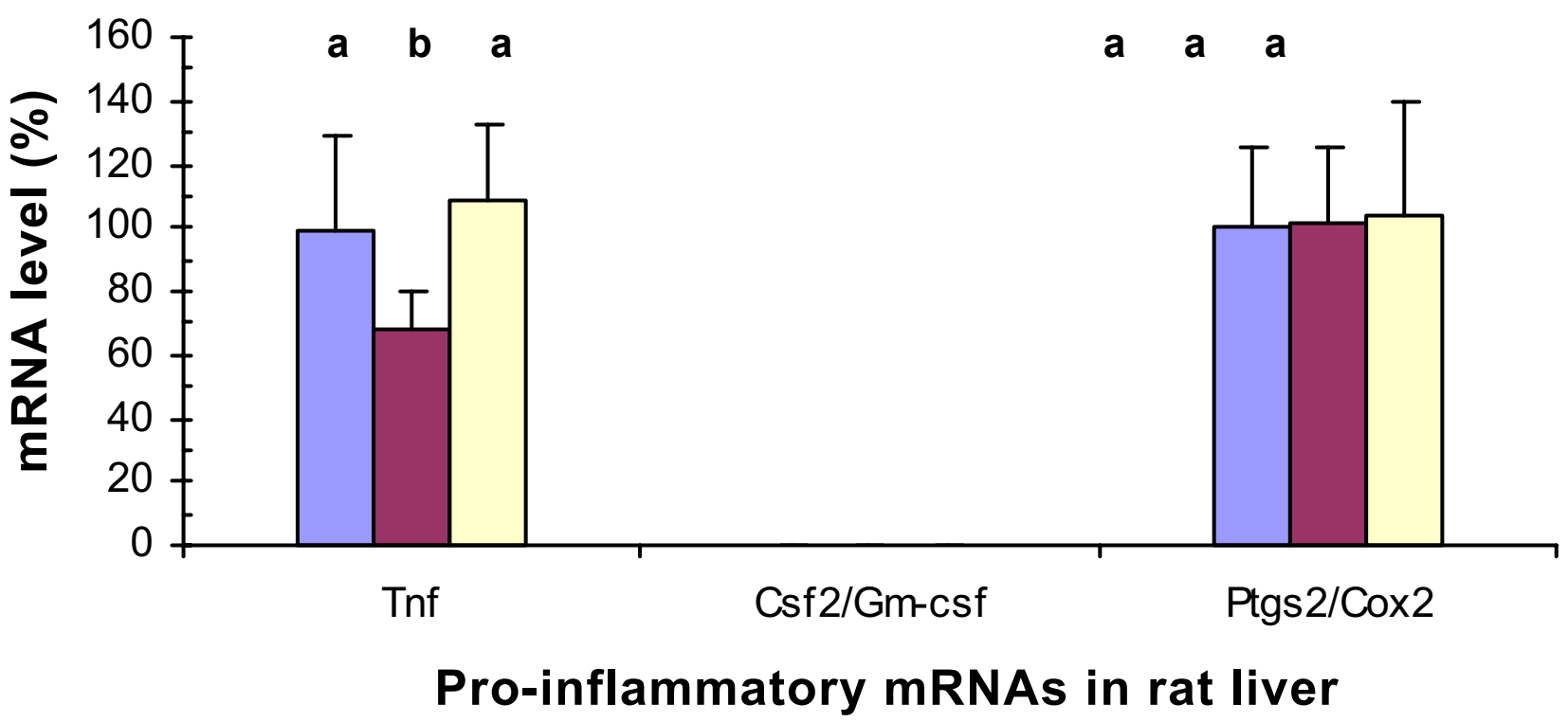

Figure 3

Green tea effects on Tnf, Csf2/Gm-csf, and Ptgs2/Cox2 mRNA levels in rat liver. RNA isolation, cDNA synthesis, real-time PCR assays, and statistical analyses were described in Fig. I legend.

nism of tea's anti-inflammatory effects may be involved in the down-regulation of pro-inflammatory cytokines such as TNF- $\alpha$ at both transcriptional and post-transcriptional levels $[8,17,18]$.

We also found that a higher dose of green tea extract at 2 $\mathrm{g}$ in the high-fructose diet significantly increased the mRNA levels of Elavl1/Hua/Hur in rat liver. ELAVL1 is known to be an RNA binding protein [33-35]. Previous studies suggest that ELAVL1 stabilizes ARE-containing mRNAs [34], but a recent study suggests that ELAVL1 in murine innate compartments suppresses inflammatory responses in vivo by inducing the translational silencing of specific cytokine mRNAs [33]. This study suggests that a higher dose of green tea might also have beneficial effects on reducing inflammation via ELAVL1 in these tissues. Vegfa and Vegfb mRNAs are known to be destabilized by TIS11B protein [32]. Our study showed that Tis $11 \mathrm{~b}$ and Vegf mRNA levels in rat liver or muscle were not affected by either tea dose. These results suggest that Vegf mRNAs may be the physiological targets of TIS11B rather than TTP in these tissues.

There are two known TTP-related proteins in mammalian cells, ZFP36L1 (TIS11B, cMG1, ERF1, BRF1, or Berg36) and ZFP36L2 (TIS11D, ERF2, or BRF2) [1]. A third related protein (ZFP36L3) was recently identified that seems to be expressed only in rodents as a placenta-specific protein [2], and the expression in other species has not been reported. These four proteins are all capable of binding to and destabilizing ARE-containing mRNAs in vitro and in transfected cells $[1,1,43]$. However, gene knockout studies have provided evidence for their unique roles in vivo. TTP knockout mice develop a severe inflammatory syndrome $[13,14]$. Mice deficient in ZFP36L1 develop chorioallantoic fusion defects and embryonic lethality [44]. Mice with decreased levels of an amino-terminal truncated form of ZFP36L2 exhibit female infertility and disrupted early embryonic development [45]. Despite their unique contributions, information is limited on the expression profiles of Ttp family mRNAs in the same tissue and/or in different tissues.

We therefore described the expression profiles of the four Ttp family mRNAs in rat liver and muscle. Real-time PCR analyses showed that Ttp and Tis $11 \mathrm{~b}$ mRNAs were the two major forms in the liver and muscle and that Ttp, Tis $11 \mathrm{~b}$, and Tis $11 \mathrm{~d}$ mRNA levels were more abundant in liver than those in muscle. The PCR results are in agreement with immunoblotting results reported previously that TTP protein levels are more abundant in mouse liver than muscle [17]. Zfp36l3 mRNA levels in the liver or muscle were below the detection limit even after 50 cycles of PCR amplification. These PCR results are in agreement with 


\section{$\square$ Diet control $\square 1 \mathrm{~g}$ tea $\square 2 \mathrm{~g}$ tea}

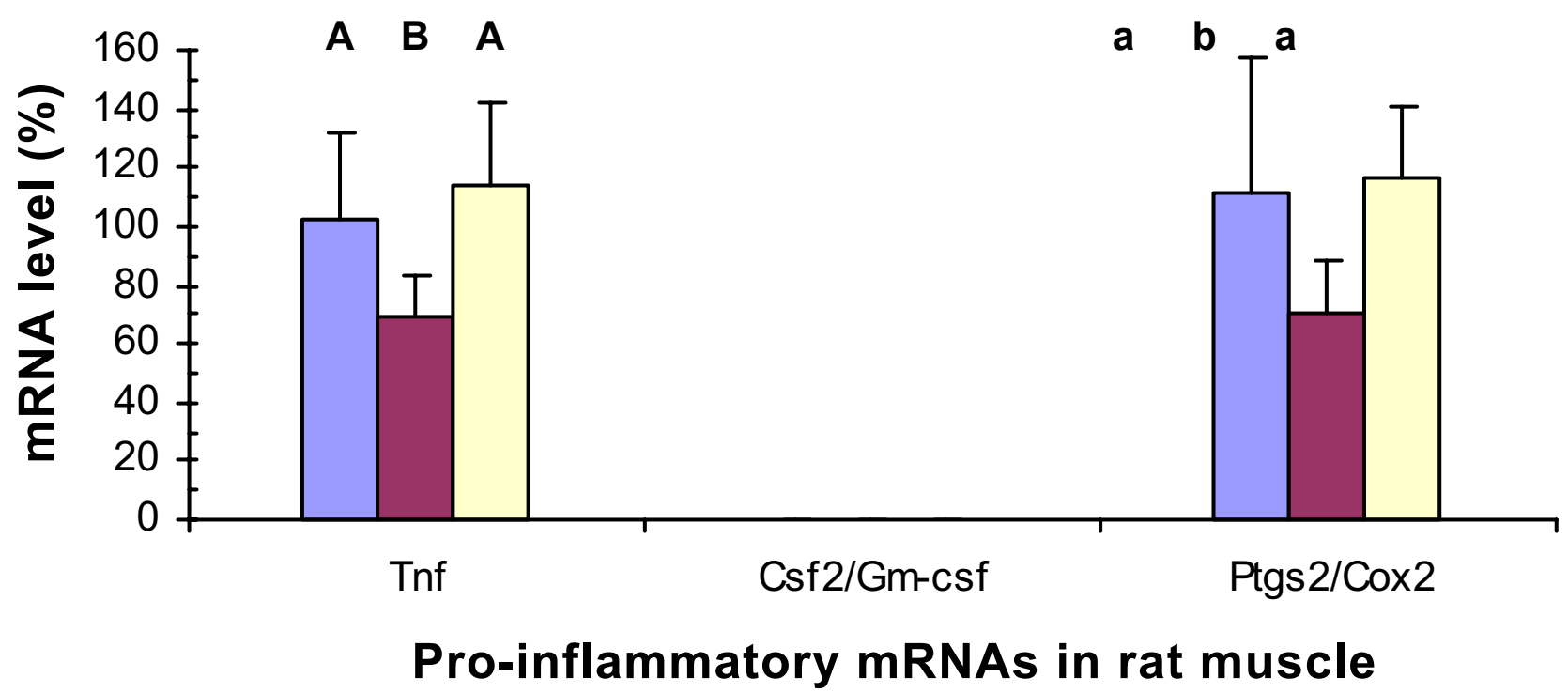

Figure 4

Green tea effects on Tnf, Csf2/Gm-csf, and Ptgs $2 /$ Cox2 mRNA levels in rat muscle. RNA isolation, cDNA synthesis, real-time PCR assays, and statistical analyses were described in Fig. I legend.

those of the Northern blot results reported previously to be specific to placenta and extra-embryonic tissues in mouse [2]. However, these expression profiles of Ttp family mRNAs in the rat liver and muscle are somewhat different from those in cultured human monocytes, in which the mRNA levels of these three forms are similar in uninduced monocytes [46].

The induction of Ttp and reduction of Tnf mRNAs in rat liver and muscle by green tea (1 g solid extract/kg high fructose diet) suggests that TTP may be involved at the post-transcriptional level in the mechanisms of tea's antiinflammatory effects. However, some issues need to be investigated in future experiments. First, the reason(s) why tea at $2 \mathrm{~g}$ solid extract $/ \mathrm{kg}$ diet did not increase Ttp mRNA levels and decreased Tnf mRNA levels in the same tissues requires further studies to determine the optimum dose that demonstrates green tea effects. It is possible that Ttp gene expression is regulated by a narrow dose of tea for certain period, since its gene expression is transiently induced by growth factors such as insulin, i.e., Ttp mRNA levels peaked at $45 \mathrm{~min}$ but declined to normal level in 2 $\mathrm{h}$ in a cell culture system [3]. Furthermore, the effect of green tea on insulin levels in the plasma showed a similar pattern, i.e., $2 \mathrm{~g}$ tea treatment was less effective than $1 \mathrm{~g}$ tea treatment. The insulin levels were $412 \pm 100 \mathrm{pmol} / \mathrm{l}, 113$ \pm 28 , and $197 \pm 43$ for the diet control, $1 \mathrm{~g}$ tea, and $2 \mathrm{~g}$ tea treatments for 6 weeks [47]. Therefore, it is important to conduct more extensive analysis of the dosage effect and time course of tea's effect on Ttp and Tnf gene expression. We believe cell culture systems could be a much more effective way to address this area of research in the future. Second, confirmation of TTP protein levels in rats with tea treatments requires future development of high-titer rat antibodies, since TTP protein is only detectable with the mouse TTP antibodies in the spleen of rats after LPS stimulation $[8,17,18]$ or in rats following dexamethasone induction [48]. Third, it's of interest to determine if the change of Tnf mRNA level correlates with the change of TNF- $\alpha$ protein level. However, since TNF- $\alpha$ is a secreted protein, a cell culture system may be more suitable to do detailed analyses of the TNF- $\alpha$ protein levels and would allow a detailed time course of the TNF- $\alpha$ protein levels. Fourth, it will be interesting to investigate if green tea has any beneficial effects in rats fed a normal diet. However, we speculate that there might be large differences in gene expression in rats treated with a high-fructose diet and a normal diet (no fructose), since the dietary environment between rats fed a normal diet and those fed a high fructose diet is dramatically different. Finally, what is the mechanism(s) of green tea activation of Ttp gene expression? Our working hypothesis is that Ttp gene expression is increased by catechins, the major polyphenols in green tea. We reported that polyphenolic compounds in cinna- 
Diet control $\square 1 \mathrm{~g}$ tea $\square 2 \mathrm{~g}$ tea

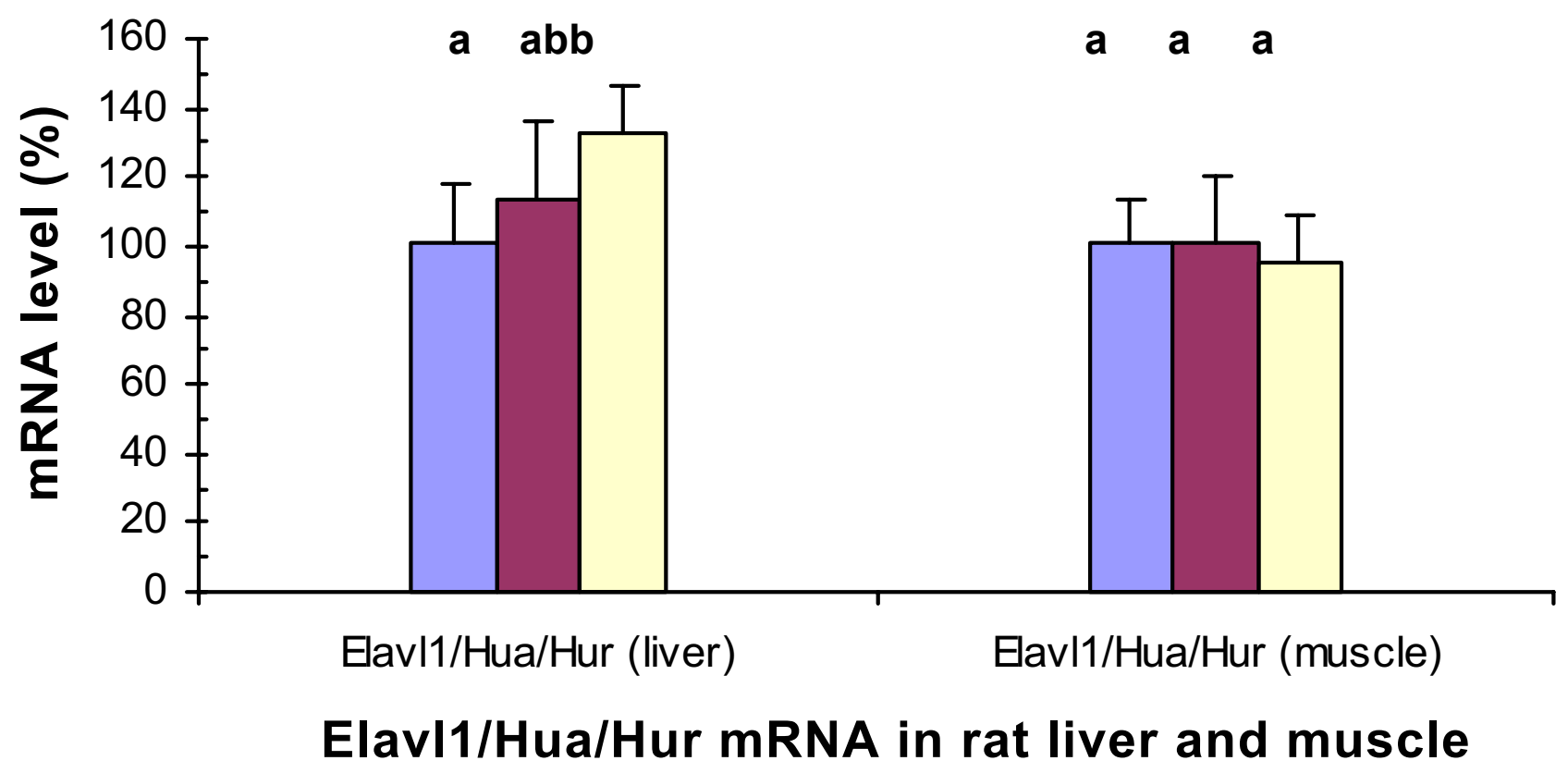

Figure 5

Green tea effects on ElavlI/Hua/Hur mRNA levels in rat liver and muscle. RNA isolation, cDNA synthesis, real-time PCR assays, and statistical analyses were described in Fig. I legend.

mon increased TTP protein levels in mouse 3T3-L1 adipocytes $[49,50]$. Recently, it was demonstrated that tea catechins directly bind to DNA and preferentially bind to poly(A), poly(U), and poly(AU) in RNA [42]. It will be interesting to investigate if green tea polyphenols could bind to the regulatory elements of Ttp gene and/or bind to the AU-rich elements in the 3'-untranslated region of Tnf mRNA, which are also the preferred binding sites for TTP protein $[51,52]$.

\section{Conclusion}

This study describes profiles of the anti-inflammatory Ttp family mRNA levels and green tea effects on these and some of the pro-inflammatory mRNAs in the liver and muscle of rats with metabolic syndrome induced by a high-fructose diet. Our results suggest that the molecular mechanism of the anti-inflammatory effects of green tea may be partially due to its ability to increase mRNA levels encoding anti-inflammatory factors such as TTP/TIS11/ ZFP36 and/or ELAVL1/HuA/HuR and to decrease mRNA levels encoding pro-inflammatory factors such as TNF- $\alpha$ and/or PTGS2/COX-2. To our knowledge, this is the first report to show that a plant nutritional product such as green tea can modulate Ttp mRNA levels in a biological system and the results provide a novel post-transcrip- tional mechanism for green tea's anti-inflammatory properties. These results suggest that drinking adequate amounts of green tea may play a role in the prevention of inflammation-related diseases.

\section{Abbreviations}

ANOVA: one way analysis of variance; ARE: AU-rich element; COX-2/PTGS2: cyclooxgenase-2/prostaglandinendoperoxide synthase 2; EGCG: Epigallocatechin-3-gallate; GM-CSF/CSF2: granulocyte-macrophage colonystimulating factor; HuR(HuA)/ELAVL1: Hu antigen R/ embryonic lethal, abnormal vision-like 1; LPS: lipopolysaccharide; NF-кB: nuclear factor-kappa B; RPL32: ribosomal protein L32; TNF: tumor necrosis factor; TTP: tristetraprolin; VEGF: vascular endothelial growth factor; ZFP36: zinc finger protein 36; ZFP36L1: ZFP36-like 1; ZFP36L2: ZFP36-like 2; ZFP36L3: ZFP36-like 3. The nomenclature of genes, mRNAs, and proteins was according to reference 1 and was accepted by the Mouse Genome Database. For example, Zfp36, Zfp36, and ZFP36 represent Zfp36 gene, mRNA, and protein, respectively.

\section{Competing interests}

The author(s) declare that they have no competing interests. 


\section{Authors' contributions}

HC designed the experiment, designed PCR primers and probes, performed PCR assays, analyzed PCR data and wrote the manuscript. MAK performed RNA isolation and cDNA synthesis. FK and HDD provided advice on RNA isolation, cDNA synthesis, and PCR assay. JFU analyzed the data and revised the manuscript. SC provided the green tea solid extract. AMR designed the animal study and provided the animal tissues. RAA designed the animal study, analyzed the data, and revised the manuscript.

\section{Acknowledgements}

This work was supported in part by USDA-ARS Human Nutrition Research Program. We thank Noella Bryden for technical assistance and Dr Alison A Yates for critically reading the manuscript. This paper is dedicated by HC to Professors Jack C Shannon and Barbara M Shannon of the Pennsylvania State University for their life-long contributions to plant science and human nutrition and for their outstanding mentorship.

\section{References}

I. Blackshear PJ: Tristetraprolin and other $\mathrm{CCCH}$ tandem zincfinger proteins in the regulation of mRNA turnover. Biochem Soc Trans 2002, 30:945-952.

2. Blackshear PJ, Phillips RS, Ghosh S, Ramos SV, Richfield EK, Lai WS: Zfp3613, a rodent $X$ chromosome gene encoding a placentaspecific member of the Tristetraprolin family of $\mathrm{CCCH}$ tandem zinc finger proteins. Biol Reprod 2005, 73:297-307.

3. Lai WS, Stumpo DJ, Blackshear PJ: Rapid insulin-stimulated accumulation of an mRNA encoding a proline-rich protein. J Biol Chem 1990, 265:16556-16563.

4. DuBois RN, McLane MW, Ryder K, Lau LF, Nathans D: A growth factor-inducible nuclear protein with a novel cysteine/histidine repetitive sequence. J Biol Chem 1990, 265:19185-19191.

5. Varnum BC, Lim RW, Kujubu DA, Luner SJ, Kaufman SE, Greenberger JS, Gasson JC, Herschman HR: Granulocyte-macrophage colony-stimulating factor and tetradecanoyl phorbol acetate induce a distinct, restricted subset of primary- response TIS genes in both proliferating and terminally differentiated myeloid cells. Mol Cell Biol 1989, 9:3580-3583.

6. Cao H: Expression, purification, and biochemical characterization of the antiinflammatory tristetraprolin: a zincdependent mRNA binding protein affected by posttranslational modifications. Biochemistry 2004, 43:13724-13738.

7. Cao H, Dzineku F, Blackshear PJ: Expression and purification of recombinant tristetraprolin that can bind to tumor necrosis factor-alpha mRNA and serve as a substrate for mitogenactivated protein kinases. Arch Biochem Biophys 2003, 412:106-120.

8. Carballo E, Lai WS, Blackshear PJ: Feedback inhibition of macrophage tumor necrosis factor-alpha production by tristetraprolin. Science 1998, 281:100|-1005.

9. Lai WS, Carballo E, Strum JR, Kennington EA, Phillips RS, Blackshear $\mathrm{PJ}$ : Evidence that tristetraprolin binds to AU-rich elements and promotes the deadenylation and destabilization of tumor necrosis factor alpha mRNA. Mol Cell Biol 1999, 19:43। I-4323.

10. Carballo E, Lai WS, Blackshear PJ: Evidence that tristetraprolin is a physiological regulator of granulocyte-macrophage colonystimulating factor messenger RNA deadenylation and stability. Blood 2000, 95:189I-1899.

II. Carballo E, Cao H, Lai WS, Kennington EA, Campbell D, Blackshear PJ: Decreased sensitivity of tristetraprolin-deficient cells to p38 inhibitors suggests the involvement of tristetraprolin in the p38 signaling pathway. J Biol Chem 200I, 276:42580-42587.

12. Sawaoka H, Dixon DA, Oates JA, Boutaud O: Tristetraprolin binds to the 3'-untranslated region of cyclooxygenase-2 MRNA. A POLYADENYLATION VARIANT IN A CANCER CELL LINE LACKS THE BINDING SITE. J Biol Chem 2003, 278:13928-13935.
13. Phillips K, Kedersha N, Shen L, Blackshear PJ, Anderson P: Arthritis suppressor genes TIA-I and TTP dampen the expression of tumor necrosis factor alpha, cyclooxygenase 2 , and inflammatory arthritis. Proc Natl Acad Sci U S A 2004, I 0 I:20 I I-20 I6.

14. Taylor GA, Carballo E, Lee DM, Lai WS, Thompson MJ, Patel DD, Schenkman DI, Gilkeson GS, Broxmeyer HE, Haynes BF, Blackshear PJ: A pathogenetic role for TNF alpha in the syndrome of cachexia, arthritis, and autoimmunity resulting from tristetraprolin (TTP) deficiency. Immunity 1996, 4:445-454.

15. Sauer I, Schaljo B, Vogl C, Gattermeier I, Kolbe T, Muller M, Blackshear PJ, Kovarik P: Interferons limit inflammatory responses by induction of tristetraprolin. Blood 2006, 107:4790-4797.

16. Cousins RJ, Blanchard RK, Popp MP, Liu L, Cao J, Moore JB, Green $C L$ : A global view of the selectivity of zinc deprivation and excess on genes expressed in human THP-I mononuclear cells. Proc Natl Acad Sci U S A 2003, 100:6952-6957.

17. Cao H, Tuttle JS, Blackshear PJ: Immunological characterization of tristetraprolin as a low abundance, inducible, stable cytosolic protein. J Biol Chem 2004, 279:2। 489-2I 499.

18. Rigby WF, Roy K, Collins J, Rigby S, Connolly JE, Bloch DB, Brooks SA: Structure/function analysis of tristetraprolin (TTP): p38 stress-activated protein kinase and lipopolysaccharide stimulation do not alter TTP function. I Immunol 2005, 174:7883-7893.

19. Taddeo B, Zhang W, Roizman B: The $U(L) 4 I$ protein of herpes simplex virus I degrades RNA by endonucleolytic cleavage in absence of other cellular or viral proteins. Proc Natl Acad Sci U SA 2006, 103:2827-2832.

20. Aydemir TB, Blanchard RK, Cousins RJ: Zinc supplementation of young men alters metallothionein, zinc transporter, and cytokine gene expression in leukocyte populations. Proc Natl Acad Sci U S A 2006, 103:1699-1704.

21. Dona M, Dell'Aica I, Calabrese F, Benelli R, Morini M, Albini A, Garbisa S: Neutrophil restraint by green tea: inhibition of inflammation, associated angiogenesis, and pulmonary fibrosis. J Immunol 2003, 170:4335-434I.

22. Haqqi TM, Anthony DD, Gupta S, Ahmad N, Lee MS, Kumar GK, Mukhtar H: Prevention of collagen-induced arthritis in mice by a polyphenolic fraction from green tea. Proc Natl Acad Sci U SA 1999, 96:4524-4529.

23. Varilek GW, Yang F, Lee EY, deVilliers WJ, Zhong J, Oz HS, Westberry KF, McClain CJ: Green tea polyphenol extract attenuates inflammation in interleukin-2-deficient mice, a model of autoimmunity. J Nutr 200I, I 3 I:2034-2039.

24. Das M, Sur P, Gomes A, Vedasiromoni JR, Ganguly DK: Inhibition of tumour growth and inflammation by consumption of tea. Phytother Res 2002, 16:S40-S44.

25. Faure $P$, Rossini E, Wiernsperger N, Richard MJ, Favier A, Halimi S: An insulin sensitizer improves the free radical defense system potential and insulin sensitivity in high fructose-fed rats. Diabetes 1999, 48:353-357.

26. Yamaguchi K, Ura N, Murakami H, Togashi N, Hyakukoku M, Higashiura K, Shimamoto K: Olmesartan ameliorates insulin sensitivity by modulating tumor necrosis factor-alpha and cyclic AMP in skeletal muscle. Hypertens Res 2005, 28:773-778.

27. Togashi N, Ura N, Higashiura K, Murakami H, Shimamoto K: The contribution of skeletal muscle tumor necrosis factor-alpha to insulin resistance and hypertension in fructose-fed rats. $J$ Hypertens 2000, 18:1605-1610.

28. Kelley GL, Allan G, Azhar S: High dietary fructose induces a hepatic stress response resulting in cholesterol and lipid dysregulation. Endocrinology 2004, 145:548-555.

29. Busserolles J, Gueux E, Rock E, Demigne C, Mazur A, Rayssiguier Y: Oligofructose protects against the hypertriglyceridemic and pro-oxidative effects of a high fructose diet in rats. I Nutr 2003, 133:1903-1908.

30. Dawson HD, Beshah E, Nishi S, Solano-Aguilar G, Morimoto M, Zhao A, Madden KB, Ledbetter TK, Dubey JP, Shea-Donohue T, Lunney JK, Urban JF Jr.: Localized multigene expression patterns support an evolving ThI/Th2-like paradigm in response to infections with Toxoplasma gondii and Ascaris suum. Infect Immun 2005, 73: $1116-1128$.

31. Livak KJ, Schmittgen TD: Analysis of relative gene expression data using real-time quantitative PCR and the 2(-Delta Delta C(T)) Method. Methods 200I, 25:402-408. 
32. Ciais D, Cherradi N, Bailly S, Grenier E, Berra E, Pouyssegur J, LaMarre J, Feige JJ: Destabilization of vascular endothelial growth factor mRNA by the zinc-finger protein TISIIb. Oncogene 2004, 23:8673-8680.

33. Katsanou V, Papadaki O, Milatos S, Blackshear PJ, Anderson P, Kollias G, Kontoyiannis DL: HuR as a negative posttranscriptional modulator in inflammation. Mol Cell 2005, 19:777-789.

34. Raghavan A, Robison RL, McNabb J, Miller CR, Williams DA, Bohjanen PR: HuA and tristetraprolin are induced following $T$ cell activation and display distinct but overlapping RNA binding specificities. J Biol Chem 200I, 276:47958-47965.

35. Atasoy U, Watson J, Patel D, Keene JD: ELAV protein HuA (HuR) can redistribute between nucleus and cytoplasm and is upregulated during serum stimulation and $\mathrm{T}$ cell activation. J Cell Sci 1998, I I I:3 |45-3 I 56.

36. Yang F, de Villiers WJ, McClain CJ, Varilek GW: Green tea polyphenols block endotoxin-induced tumor necrosis factorproduction and lethality in a murine model. I Nutr 1998, I 28:2334-2340.

37. Menegazzi M, Tedeschi E, Dussin D, de Prati AC, Cavalieri E, Mariotto $\mathrm{S}$, Suzuki $\mathrm{H}$ : Anti-interferon gamma action of epigallocatechin-3-gallate mediated by specific inhibition of STATI activation. FASEB / 200I, I 5: |309-13 | I.

38. Tedeschi E, Menegazzi M, Yao Y, Suzuki H, Forstermann U, Kleinert $\mathrm{H}$ : Green tea inhibits human inducible nitric-oxide synthase expression by down-regulating signal transducer and activator of transcription-Ialpha activation. Mol Pharmacol 2004, 65:111-120.

39. Anderson RA, Polansky MM: Tea enhances insulin activity. J Agric Food Chem 2002, 50:7182-7I86.

40. Broadhurst CL, Polansky MM, Anderson RA: Insulin-like biological activity of culinary and medicinal plant aqueous extracts in vitro. J Agric Food Chem 2000, 48:849-852.

4I. Li C, Allen A, Kwagh J, Doliba NM, Oin W, Najafi H, Collins HW, Matschinsky FM, Stanley CA, Smith TJ: Green tea polyphenols modulate insulin secretion by inhibiting glutamate dehydrogenase. J Biol Chem 2006, 28 I: 10214-10221.

42. Kuzuhara T, Sei Y, Yamaguchi K, Suganuma M, Fujiki H: DNA and RNA as New Binding Targets of Green Tea Catechins. J Biol Chem 2006, 28I: 17446-17456.

43. Anderson P, Phillips K, Stoecklin G, Kedersha N: Post-transcriptional regulation of proinflammatory proteins. J Leukoc Biol 2004, 76:42-47.

44. Stumpo DJ, Byrd NA, Phillips RS, Ghosh S, Maronpot RR, Castranio T, Meyers EN, Mishina Y, Blackshear PJ: Chorioallantoic fusion defects and embryonic lethality resulting from disruption of Zfp36LI, a gene encoding a CCCH tandem zinc finger protein of the tristetraprolin family. Mol Cell Biol 2004, 24:6445-6455

45. Ramos SB, Stumpo DJ, Kennington EA, Phillips RS, Bock CB, RibeiroNeto F, Blackshear PJ: The CCCH tandem zinc-finger protein Zfp3612 is crucial for female fertility and early embryonic development. Development 2004, I 3 1:4883-4893.

46. Carrick DM, Lai WS, Blackshear PJ: The tandem CCCH zinc finger protein tristetraprolin and its relevance to cytokine mRNA turnover and arthritis. Arthritis Res Ther 2004, 6:248-264.

47. Anderson RA, Hininger I, Coves S, Roussel AM: Tea increases insulin sensitivity and decreases oxidative stress in rats with metabolic syndrome [abstract]. Proceedings of the 18th International Congress of Nutrition 2005: I.3.1..

48. Smoak K, Cidlowski JA: Glucocorticoids regulate tristetraprolin synthesis and posttranscriptionally regulate tumor necrosis factor alpha inflammatory signaling. Mol Cell Biol 2006, 26:9126-9135

49. Cao H, Polansky MM, Blackshear PJ, Anderson RA: Insulin and cinnamon polyphenols increase the amount of insulin receptor b, glucose transporter 4 , and anti-inflammatory protein tristetraprolin in mouse 3T3-LI adipocytes [abstract]. FASEB J 2006, 20:A93.

50. Cao H, Polansky MM, Anderson RA: Cinnamon extract and polyphenols affect the expression of tristetraprolin, insulin receptor, and glucose transporter 4 in mouse 3T3-LI adipocytes. Arch Biochem Biophys 2007:in press.

51. Blackshear PJ, Lai WS, Kennington EA, Brewer G, Wilson GM, Guan $X$, Zhou $P$ : Characteristics of the interaction of a synthetic human tristetraprolin tandem zinc finger peptide with AU. rich element-containing RNA substrates. I Biol Chem 2003, 278: 19947-19955.

52. Worthington MT, Pelo JW, Sachedina MA, Applegate JL, Arseneau $\mathrm{KO}$, Pizarro TT: RNA binding properties of the AU-rich element-binding recombinant Nup475/TISII/tristetraprolin protein. J Biol Chem 2002, 277:48558-48564.
Publish with Bio Med Central and every scientist can read your work free of charge

"BioMed Central will be the most significant development for disseminating the results of biomedical research in our lifetime. "

Sir Paul Nurse, Cancer Research UK

Your research papers will be:

- available free of charge to the entire biomedical community

- peer reviewed and published immediately upon acceptance

- cited in PubMed and archived on PubMed Central

- yours - you keep the copyright

Submit your manuscript here:

http://www.biomedcentral.com/info/publishing_adv.asp
BioMedcentral 